\title{
Children's health care assistance according to their families: a comparison between models of Primary Care*
}

\author{
Assistência à saúde da criança segundo suas famílias: \\ comparação entre modelos de Atenção Primária \\ Asistencia a la salud del niño según sus familias: comparación \\ entre modelos de Atención Primaria
}

Vanessa Bertoglio Comassetto Antunes de Oliveiraㅁ, Maria de La Ó Ramallo Veríssimo²

\footnotetext{
* Extracted from the thesis "Evaluation of Primary Child Health in the municipality of Colombo- Paraná," Graduate Program in Nursing, School of Nursing, University of São Paulo, 2012.

${ }^{1} \mathrm{PhD}$ student in Health Sciences, Graduate Program in Nursing, School of Nursing, University of São Paulo, São Paulo, SP, Brazil.

${ }^{2}$ Professor, Department Maternal-Child and Psychiatric Nursing School, University of São Paulo, São Paulo, SP, Brazil.
}

\section{ABSTRACT}

Objective: To compare the health assistance models of Basic Traditional Units (UBS) with the Family Health Strategy (ESF) units for presence and extent of attributes of Primary Health Care (APS), specifically in the care of children. Method: A crosssectional study of a quantitative approach with families of children attended by the Public Health Service of Colombo, Paraná. The Primary Care Assessment Tool (PCA-Tool) was applied to parents of 482 children, $235 \mathrm{ESF}$ units and $247 \mathrm{UBS}$ units covering all primary care units of the municipality, between June and July 2012. The results were analyzed according to the PCA-Tool manual. Results: ESF units reached a borderline overall score for primary health care standards. However, they fared better in their attributes of Affiliation, Integration of care coordination, Comprehensiveness, Family Centeredness and Accessibility of use, while the attributes of Community Guidance/Orientation, Coordination of Information Systems, Longitudinality and Access attributes were rated as insufficient for APS. UBS units had low scores on all attributes. Conclusion: The ESF units are closer to the principles of APS (Primary Health Care), but there is need to review actions of child care aimed at the attributes of APS in both care models, corroborating similar studies from other regions of Brazil.

\section{DESCRIPTORS}

Child; Primary Health Care; Health Evaluation; Child Health; Family Health Strategy. 


\section{INTRODUCTION}

After more than thirty years since the Alma Ata Conference, Primary Health Care (APS) has consolidated as one of the most equitable and efficient ways to organize a health system ${ }^{(1)}$ by advocating equitable care with quality to the population, among other benefits. The Pan American Health Organization (PAHO) defines Primary Health Care as a "strategy for organizing health care systems in order to enable universal access to services and comprehensive and integrated care over time" ${ }^{\prime 1-2)}$.

At the national level, the Ministry of Health adopted the Family Health Strategy (ESF) in 1994 to reorganize the Unified Health System (SUS) and expand the APS. According to the Ministry of Health in Brazil ${ }^{(3)}$, the number of family health teams deployed and funding for the expansion of the ESF have both increased, reaching/covering $52.1 \%$ of the Brazilian population.

The scientific literature provides evidence of the association between greater APS orientation and increasing the effectiveness of health systems, promotion of fairness, user satisfaction and efficiency ${ }^{(4)}$. It is noteworthy that most of the studies are centered on the health systems of developed countries $^{(4)}$. However, there is evidence of the positive impact of APS on the health systems of developing countries, primarily those which are located in Latin America.

On the international scene, it has been observed ${ }^{(5-6)}$ that increasing ESF coverage is linked to reducing infant mortality and promoting greater equity. Such evidence is present in the national results ${ }^{(7-8)}$, studies which also indicate a higher quality of prenatal care, child care, offering use of health services, although in a low effectiveness context throughout the public health system.

With the purpose of understanding the APS guidelines, Starfield et al. ${ }^{(9)}$ proposed a broad concept directed at the presence and extension of essential attributes and derivatives in the service.

The essential attributes of $\mathrm{PHC}$ are: Access at first contact, which is the accessibility and usability of the service at each new problem or a new episode of a problem; Longitudinality, which presupposes the existence of a regular form of attention and its use over time; Comprehensiveness which involves making arrangements for the patient to receive all types of health services; Coordination, which is the availability of information about problems and previous services and the recognition of that information in that it is related to the needs for this service.

The derived attributes of PHC in turn are: Family orientation, arising from the consideration of the family context in the care provided; Community orientation, which arises from the recognition of social needs ${ }^{(9)}$.

To assess the presence and the extension of these APS attributes, a Primary Care Assessment Tool (PCA-Tool) was prepared which is validated in adult, child and professional versions. This instrument produces scores for each attribute, allowing the evaluation of each of them separately ${ }^{(10)}$, as well as an overall score, measuring the degree of APS orientation in different services and health systems.
Some municipalities have had their health system evaluated by a PCA-Tool with several objectives: to separately evaluate health services for children and adults, comparing different city services and also various study populations, whether users or health professionals ${ }^{(11-14)}$.

This study aims to compare the presence and extension of APS attributes for child health care between ESF Units and Basic Traditional Units (UBS) in the city of Colombo, Paraná, Brazil, through the application of a PCA-Tool on those responsible for the children receiving/using the service.

The council began the implementation of the Family Health Strategy into their health facilities in 2000 and has sought to adapt the services to Primary Care. Thus, this evaluation study may be useful for the development of methods and strategies for action ${ }^{(15)}$.

\section{METHOD}

A cross-sectional study with a quantitative approach, conducted with families responsible for children who were attended by the public health service in Colombo during 2011 and early 2012, being gathered between June and July 2012.

Colombo composes the metropolitan region of Curitiba, the capital of Paraná; its population is estimated at 247 , 268 inhabitants, 21, 227 children between 0 and 5 years $^{(16)}$. The health system has 21 health units, 9 integrated into the Family Health Strategy (EFS) and the rest are Basic Traditional Units (UBS). The choice of this town is appropriate because there is interest in adapting their local health service to the attributes of APS. Thus, there is a demand for evaluative studies to guide this adaptation process.

For the evaluation, the study used the experience of families responsible for registered and assiduous children of health facilities in the municipality. The research population was comprised of children registered in all 21 Basic Health Units who had turned 1 year old during the period of data collection as the higher frequency of health consultations occur in the first year of life which enhances the experiences of families in caring for their children at health facilities. There were 590 children served by the Basic Units and 525 children served by the Family Health Strategy Units in this age group.

In a simple sample calculation with $95 \%$ confidence and 3\% maximum estimate error for both samples (optimal values for evaluation research) ${ }^{(17)}$, the total came to 235 subjects for the population of Family Health Strategy units and 247 for the Basic Units, totaling 482 subjects. Inclusion criteria were children born between January 1 and June 30, 2011, and registered in the Child Care Program of the unit. The respondent should be the one responsible for the child (father, mother, uncle, aunt, grandparent or legal guardian) and habitually escort the child to the health service and be able to provide recorded/maintained communication. The number of visits by the children to the health unit being less than three was adopted as an exclusion criterion.

A child version PCA-Tool ${ }^{(10)}$ containing 49 items was used to measure the presence of ten attributes of primary care. According to the Likert model for each state- 
ment about the care practices in service, the respondent chose one among the following alternatives: definitely yes; probably yes; probably not; certainly not; and do not know / do not remember. For each alternative, the instrument gives a score $(4,3,2,1$ and 9, respectively) whose sum is then transformed into scores by statistical calculations defined in the PCA-Tool manual. The greater than or equal to 6.6 scores are considered to be an adequate score for $\operatorname{APS}^{(10)}$.

The interviews were conducted in the participants' homes by interviewers trained by the researcher.

The project was approved by the Ethics Committee of Research of the School of Nursing of Universidade de São Paulo, under the CAAE number 02559112.2.0000.5392 and the Health Department of Colombo. Only interviews with officials who agreed to participate and signed the consent form were conducted.

\section{RESULTS}

The study sample was composed mostly of mothers whose children had been attended by the health service, followed by grandparents, parents and aunts, respectively, with over $90 \%$ of female subjects in both groups. Regarding education, $96 \%$ of them were considered literate. The age of participants ranged from those linked to the UBS and the $\mathrm{ESF}$; for the first, most were under 20 years and, in the ESF, the average age was between 20 and 30 years.

Figure 1 shows the scores for each attribute of primary care, showing a statistically significant difference between the two models of care, with the better performing units being those of ESF.

In analyzing the performance of the units, the overall score of primary care for all the attributes reached 6.6 in the EFS units, while it was just 3.9 in the Basic Health Units. Overall scores of each attribute shown in Figure 1 will be described in sequence and linked to the data in Table 1, which shows the scores for each item comprising the evaluation of the attribute.

Regarding the Degree of Affiliation, the overall score of 9 from ESF units against 1.7 of UBS units (Figure 1) indicates that the families of children registered in ESF identify that professionals know details about the child, not only focusing on their health / disease.

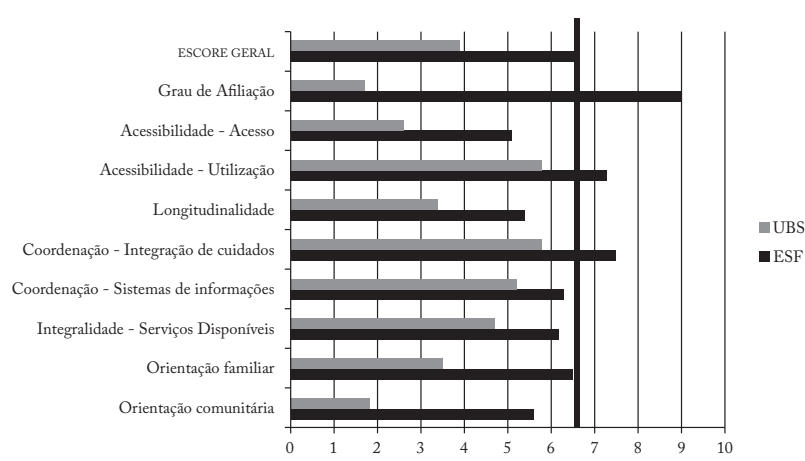

Translation legend: Escore Geral = Overall score, Grau de afiliação $=$ degree of membership/affiliation, Acessibilidade - Acesso $=$ Accessibility of access, Acessibilidade - Utilização $=$ Accessiblity of use, Longitudinalidade $=$ Longitudinality, Coordenação - Integração de cuidados = Coordination - Integration of care, Coordenação - Sistemas de Informações = Coordination of Information Systems, Orientação familiar = Family Centeredness Orientação comunitária $=$ Community Orientation

Figure 1 - Mean values of scores for each related to organizational characteristics and performance of primary care attributes, according to the type of unit Primary Care Network of the city of Colombo, PR, 2012.

The score of the First Contact Access - Usage attribute was 7.3 for ESF units and 5.8 for UBS (Figure 1). The ESF units are the priority access entry for families, more than the traditional basic units (Table 1).

The Accessibility attribute scores were 5.1 for ESF units and 2.6 for UBS (Figure 1). In both types of service, the access to care is difficult and time consuming although it is worse in the UBS units (Table 1).

Longitudinality was also an attribute that did not reach the minimum value for APS, and the score for ESF units was 5.4 and 3.4 for UBS (Figure 1). Although ESF has obtained adequate scores on some items, overall there is a deficiency for both units in the regularity of continuous attention to the child (Table 1 ).

Table 1 - Mean values, standard errors and corresponding value of the statistical significance of T test for each of the attributes and items that comprise the scale - Colombo, PR, 2012.

\begin{tabular}{|c|c|c|c|c|c|}
\hline \multirow{3}{*}{ Indicador } & \multirow{2}{*}{\multicolumn{2}{|c|}{$\begin{array}{c}\text { ESF } \\
(n=235)\end{array}$}} & \multirow{2}{*}{\multicolumn{2}{|c|}{$\begin{array}{c}\text { UBS } \\
(n=247)\end{array}$}} & \multirow{3}{*}{ T Test } \\
\hline & & & & & \\
\hline & Score & Ep & Score & Ep & \\
\hline \multicolumn{6}{|l|}{ First contact access - Usage } \\
\hline You go to your healthcare provider before going to another for a routine appointment & 7,3 & 0,18 & 5 & 0,18 & $<0,001^{*}$ \\
\hline You go to your healthcare provider before you go to another for a new problem & 7,6 & 0,149 & 4,7 & 0,16 & $<0,01^{*}$ \\
\hline Your health service sends you to a specialist when necessary & 7 & 0,188 & 7,6 & 0,16 & $0,020006^{*}$ \\
\hline \multicolumn{6}{|l|}{ First contact access - Accessibility } \\
\hline The health service attends you in the same day & 6,4 & 0,187 & 4,3 & 0,17 & $<0,0001^{*}$ \\
\hline There is a long wait to schedule an appointment & 4,7 & 0,209 & 1,8 & 0,13 & $<0,0001^{*}$ \\
\hline It's easy to make an appointment for a routine checkup for a child & 5,9 & 0,182 & 3,2 & 0,14 & $<0,0001 *$ \\
\hline You have to wait more than 30 minutes for an appointment & 3,7 & 0,175 & 1,2 & 0,11 & $<0,0001^{*}$ \\
\hline
\end{tabular}


...continuation

\begin{tabular}{cccccc}
\multicolumn{2}{c}{ ESF } & \multicolumn{2}{c}{ UBS } & \multirow{2}{*}{ T Test } \\
\cline { 1 - 4 }$(\mathbf{n}=\mathbf{2 3 5})$ & \multicolumn{2}{c}{$(\mathbf{n = 2 4 7 )}$} & \\
\cline { 1 - 4 } Score & Ep & Score & Ep & \\
\cline { 1 - 3 } 6,2 & 0,161 & 2,6 & 0,16 & $<0,01^{*}$ \\
3,9 & 0,176 & 2,7 & 0,13 & $<0,0001^{*}$ \\
& & & & \\
7 & 0,166 & 2,8 & 0,14 & $<0,01^{*}$ \\
3,7 & 0,148 & 2,6 & 0,14 & $<0,0001^{*}$ \\
7,3 & 0,153 & 4,3 & 0,15 & $<0,01^{*}$ \\
4,6 & 0,159 & 4,1 & 0,16 & $0,018601^{*}$ \\
5,7 & 0,188 & 5,4 & 0,18 & 0,195223 \\
3,6 & 0,165 & 2,3 & 0,14 & $<0,0001^{*}$ \\
4,5 & 0,19 & 3,1 & 0,15 & $<0,0001^{*}$ \\
5,2 & 0,193 & 2,7 & 0,14 & $<0,0001^{*}$ \\
5,9 & 0,178 & 4,4 & 0,17 & $<0,0001^{*}$ \\
6 & 0,175 & 2,9 & 0,14 & $<0,01^{*}$ \\
5,7 & 0,192 & 2,4 & 0,13 & $<0,01^{*}$ \\
& & & & \\
8,1 & 0,11 & 5,3 & 0,14 & $0,001156^{*}$ \\
7,7 & 0,104 & 6 & 0,16 & $0,063386^{*}$ \\
7,9 & 0,13 & 7 & 0,12 & 0,252483 \\
6,3 & 0,16 & 5 & 0,15 & 0,176225 \\
7,7 & 0,163 & 5,7 & 0,14 & $0,038722^{*}$
\end{tabular}

The professional of your service expressed an interest in your appointment with the specialist

It's difficult to get medical attention in the service

You have been able to get information over the phone in the service

\section{Longitudinality}

It's the same professional that attends my child in the service

You can call to speak to the professional in the service

The professional understands what you say or ask

The professional answers your questions in a way that you can understand

You feel comfortable to talk to the professional about your child's problems

The professional gives you enough time to talk about your problems or concerns

The professional recognizes the child as a person and more than just a health problem

The professional knows the health/clinical history of the child

The professional knows the medication that the child takes

The professional will meet with the family if necessary

You would move to another health service if it were easy

\section{Coordination / Integration of Care}

The professional of your service knows of your appointment with a specialist

The professional of your service knew the results of your appointment with the specialist

Your service recommended a specialist for you

After your appointment with the specialist, the professional of your service spoke with you

Coordination - Information Systems

You take your vaccination record to your appointments

The medical records of the child are always available in consultations/appointments

You have access to the child's medical records

\section{Comprehensiveness of Available Services}

Social Assistance Program

Family Planning

Supplemental nutrition program

Drug use counseling

Vaccines

Counseling for mental health problems

Suturing/stitching

STD Counseling and HIV testing

Eye and vision health testing

\section{Family Centeredness}

The professional knows your family well enough

The professional knows the main problems in your family

The professional knows the employment of the child's parents/guardians

The professional would know the problems of family to get medications

The professional asks your opinion about the child's treatment

The professional knows the health problems/medical history of the family

\section{Community Orientation}

Someone from your health service makes home visits

Your health service knows the neighborhood health problems

Your health service does research in the community to identify problems

Your health service invites family members to participate in Health Counselling
$7,4 \quad 0,118 \quad 6,1 \quad 0,16 \quad<0,0001 *$

$5,8 \quad 0,168 \quad 5,2 \quad 0,17 \quad 0,007427^{*}$

$5,7 \quad 0,177 \quad 4,2 \quad 0,16<0,0001^{*}$

$6,4 \quad 0,15 \quad 4,1 \quad 0,17 \quad<0,0001^{*}$

$7,2 \quad 0,146 \quad 4,9 \quad 0,17 \quad<0,0001^{*}$

$5,4 \quad 0,18 \quad 4,6 \quad 0,16 \quad 0,003841^{*}$

$4,6 \quad 0,177 \quad 3,4 \quad 0,13<0,0001^{*}$

$8,2 \quad 0,116 \quad 8,4 \quad 0,11 \quad 0,357689$

$5,2 \quad 0,167 \quad 3,5 \quad 0,14<0,0001^{*}$

$7,4 \quad 0,158 \quad 5,5 \quad 0,15<0,0001^{*}$

$5 \quad 0,182 \quad 4 \quad 0,17 \quad 0,000296^{*}$

$6 \quad 0,174 \quad 4 \quad 0,15<0,0001$ *

$6 \quad 0,132 \quad 3,3 \quad 0,14<0,01 *$

$5,9 \quad 0,209 \quad 3,2 \quad 0,14<0,0001^{*}$

$5,3 \quad 0,151 \quad 2,4 \quad 0,14 \quad<0,01 *$

$5,3 \quad 0,153 \quad 2,6 \quad 0,14 \quad<0,01 *$

$6,1 \quad 0,16 \quad 4,5 \quad 0,18<0,001^{*}$

$6,9 \quad 0,148 \quad 4,8 \quad 0,18<0,001^{*}$

$7,6 \quad 0,143 \quad 1,2 \quad 0,1 \quad<0,01 *$

$5,8 \quad 0,162 \quad 2,7 \quad 0,13<0,01 *$

$5,4 \quad 0,175 \quad 1,4 \quad 0,1 \quad<0,01 *$

$3,6 \quad 0,155 \quad 1,9 \quad 0,12<0,0001^{*}$

* Statistically significant values

Note: Interviewees (caretakers of children). 
Coordination is divided into Integrated Care and Information Systems. The Integration of Care score reached 7.7 for ESF, while UBS resulted in a score of 5.8 (Figure 1). ESF units are more integrated with the specialized services than UBS units (Table 1). Regarding Information Systems, ESF units received scores of 6.3, while UBS received 5.2 (Figure 1). The recording of information as well as user access to these records is happening inefficiently, or is not occurring in either service (Table 1).

With regards to the Comprehensiveness attribute, the EFS units had a score of 6.2, higher than UBS which received 4.7 (Figure 1). Only some services or programs are adequately available, such as vaccinations in both units, while Family Planning and stitching is only available in the ESF units (Table 1).

Family Centeredness attributes had ESF units with a score of 6.5 and UBS had 3.5 (Figure 1). The approach of the professional to the families in the care and guidance of children is insufficient in UBS and slightly lower than expected in ESF (Table 1).

In the last attribute evaluated, Community Orientation had a large difference between scores, but the ESF units obtained 5.6, while UBS only reached 1.8 (Figure 1). In both services, it was noted that the professionals have insufficient knowledge of the community to which children belong; therefore, they are not connecting the child care to the reality of the community (Table 1).

\section{DISCUSSION}

The dialogue provided by the reading and analysis of the results identified that in the regional context ESF units are consistent with APS when analyzing the overall score. However, the Basic Traditional Unit (UBS) scores do not reach Primary Care (APS) standards for the care of children. Studies from other regions nationwide corroborate the finding in traditional units, identifying difficulties experienced with respect to meeting the objectives of APS ${ }^{(11-14)}$. The only scores that identified as suitable for APS in ESF units were found in Curitiba ${ }^{(14)}$.

The results found in this study with respect to ESF units are satisfactory since this is considered a strategy to change the traditional way of providing assistance to stimulate the implementation of a model which favors Primary Care (APS), targeting comprehensive care for the user as an integrated subject of family, the household and the community ${ }^{(18)}$.

These units however, did not have satisfactory performance in all attributes. It was observed that the positive evaluations are related to the unit's resolution to be the priority entry by way of the trust established by the professional teams, as well as the interaction established by the ESF with specialized services.

On the other hand, several individual attributes do not reach the required score for APS, denoting that some barriers which are desired to be broken through are still present, even in ESF units. Such problems consist in difficult and time consuming access to services, the unavailability of information in the attendance records and lack of access to those records by the users, the absence of some programs and services for children and their families, insufficient knowledge of the professional about the children, family and community in which they are working, and a deficiency in continuous regularity of attention to the child.

It may be suggested that some of these difficulties are the same for the two models of care. Some studies discuss problems in the financing of Primary Care and Family Health Strategy at the local level, due to the instability of their resources themselves and by the consequences arising from systematic state and federal financial incentives to the autonomy of the local health system ${ }^{(19)}$.

The advantage of a larger financial incentive is to promote the development of appropriate actions to the goals of APS. The increase of financial resources can be considered as a decisive factor for hiring more health professionals, decreasing the wait for an appointment, in addition to encouraging the presence and continuity of good professionals through consistent wages ${ }^{(20)}$. Furthermore, it allows for an adequate (computerized) information system that favors the registration and access of health information of the population.

Another obstacle for both models has historical counterpoints and difficulty to change. The traditional public health is constituted by the image and similarity of technoscience and the biomedical model, and is still ingrained in the practices of health care professionals ${ }^{(21)}$. Some authors correlate this problem to the difficulty in obtaining qualified professionals working in the ESF model and to rethink the issue of health promotion depending on the educational practices, as highlighted by the assumptions of APS ${ }^{(22-25)}$. This situation happens as a result of the training model of these professionals: hospital centric, biologistic and fragmented $^{(24)}$. In most educational institutions of healthcare professionals (nurses, doctors etc.), health education is defined in a purely clinical education and biomedical para$\operatorname{digm}^{(24)}$. This approach favors the onset of problems such as the distance of the professional from the patient and their family, difficulties in understanding the dialogue between those involved and denial/rejection of knowledge coming from patients.

This fact justifies the fact that ESF units have far from ideal scores for APS on key attributes such as Accessibility, Longitudinality, Integration of Care, Information Systems and Comprehensiveness, and derived attributes (Family Centeredness and Community Orientation). For this reason, it is important to reiterate the relevance of continuing education and restructuring of undergraduate courses, so as to bring the practice of health education closer to the social reality, thereby conforming more to the attributes defined by the APS.

At the same time, thinking turned to the logic of promotion and prevention is not yet present in the population; they seek solutions/cures to diseases already inflicted. It is suggested that increasing education around the importance of prevention awareness will be more closely aligned to APS for the UBS and ESF services. That way, people can be more active subjects in the health and illness processes of their families ${ }^{(22)}$. When services are restricted to provide 
curative care/treatment over preventative and promotional health, this leads to losses of membership, as well as lack of establishing linkages to the patients, and a lack of care integration and longitudinality.

It was observed that some practices could be changed, requiring fewer resources and contributing to achieving the objectives of the APS attributes; for example allowing the user to access the child's records, ensuring a communication interface with the specialized services, informing the family and the community in the care of the subject and opportunizing times for the population to have access to staff via phone. This is aligned with findings from other national research, especially with those conducted in southeastern Brazil(26).

\section{CONCLUSION}

In the assessment process, ESF units obtained satisfactory results. Positive factors were identified in the care provided by these health facilities and they shall endeavor to maintain sufficient quality of service provided in relation to
APS. However, it is fundamental to rethink some service quality factors that are insufficient in meeting APS standards.

There is still much to produce in order to evaluate health services nationwide, including providing a regional comparison between APS performances in order to improve attendance throughout the national territory.

Limitations may be recognized in this study. This evaluation only included the experience of those responsible for children attending the services, which is very possibly linked to their needs, thereby masking a broader view of reality. This could be improved through other analyzes that seek to determine the impact of each attribute individually, the degree of APS orientation, confronting it with health outcomes.

At the same time, it was observed that there are ways in which subjects are still dissatisfied with the service provided. Disorders in acute conditions, waiting time for service, geographical or scheduling difficulties for consultation, a lack of public transportation, difficulties in searching for specialists and receiving examinations are some factors that may be associated with these results.

\section{RESUMO}

Objetivo: Comparar o modelo assistencial de Unidades Básicas Tradicionais (UBS) com as unidades Estratégia Saúde da Família (ESF) quanto à presença e extensão dos atributos da Atenção Primária de Saúde (APS), no atendimento de crianças. Método: Estudo transversal, com abordagem quantitativa, com familiares de crianças atendidas no Serviço Público de Saúde de Colombo, Paraná. O Primary Care Assessment Tool (PCA-Tool) foi aplicado aos responsáveis de 482 crianças, 235 de unidades ESF e 247 de UBS, abrangendo todas as unidades de atenção primária do município, entre junho e julho de 2012. Os resultados foram analisados segundo o manual do PCA-Tool. Resultados: As unidades com ESF alcançaram escore geral limítrofe para APS. Porém, tiveram melhores resultados nos atributos Afiliação, Coordenação da integração dos cuidados, Integralidade, Orientação Familiar e Acessibilidade quanto à utilização, enquanto os atributos Orientação Comunitária, Coordenação dos sistemas de informações, Longitudinalidade e Acesso foram classificados como insuficientes para a APS. As UBS tiveram escores baixos em todos os atributos. Conclusão: As unidades com ESF estão mais próximas dos princípios da APS, mas há necessidade de rever ações de assistência à criança, visando aos atributos da APS, em ambos os modelos de atenção, corroborando com estudos semelhantes em outras regiões do Brasil.

\section{DESCRITORES}

Criança; Atenção Primária à Saúde, Avaliação em Saúde, Saúde da Criança; Estratégia Saúde da Família.

\section{RESUMEN}

Objetivo: Comparar el modelo asistencial de Unidades Básicas Tradicionales (UBS) con las unidades Estrategia Salud de la Familia (ESF) en cuanto a la presencia y extensión de los atributos de la Atención Primaria de Salud (APS), en la atención a los niños. Método: Estudio transversal, con abordaje cuantitativo, con familiares de niños atendidos en el Servicio Público de Salud de Colombo, Paraná. El Primary Care Assessment Tool (PCA-Tool) fue aplicado a los responsables de 482 niños, 235 de unidades ESF y 247 de UBS, abarcando todas las unidades de atención primaria del municipio, entre junio y julio de 2012. Los resultados fueron analizados según el manual del PCA-Tool. Resultados: Las unidades con ESF alcanzaron un puntaje general limítrofe para APS. Sin embargo, tuvieron mejores resultados en los atributos Afiliación, Coordinación de la integración de los cuidados, Integralidad, Orientación Familiar y Accesibilidad en cuanto a la utilización, mientras que los atributos Orientación Comunitaria, Coordinación de los sistemas de informaciones, Longitudinalidad y Acceso fueron clasificados como insuficientes para la APS. Las UBS tuvieron puntajes bajos en todos los atributos. Conclusión: Las unidades con ESF se acercan más a los principios de la APS, pero existe la necesidad de rever acciones de asistencia al niño, con vistas a los atributos de la APS, en ambos modelos de atención, corroborando con estudios semejantes en otras regiones de Brasil.

\section{DESCRIPTORES}

Niño; Atención Primaria de la Salud, Evaluación de la Salud; Salud del Niño; Estrategia de Salud Familiar.

\section{REFERENCES}

1. Paim, JS. A constituição cidadã e os 25 anos do Sistema Único de Saúde (SUS). Cad Saúde Pública [Internet]. 2013 [citado 2013 out. 23];29(10). Disponível em: http://www.scielo.br/pdf/csp/v29n10/a03v29n10.pdf

2. Organização Pan-Americana da Saúde; Organização Mundial da Saúde. Renovação da atenção primária em saúde nas Américas: documento de posicionamento da OPAS/OMS. Washington: OPAS; 2007. 
3. Brasil. Ministério da Saúde; Secretaria de Atenção à Saúde, Departamento de Ações Programáticas e Estratégicas. Agenda de compromisso para a saúde integral da criança e redução da mortalidade infantil [Internet]. Brasília; 2005 [citado 2012 mar. 16]. Disponível em: http:// bvsms.saude.gov.br/bvs/publicacoes/agenda_compro_crianca.pdf

4. Souza MLB, Melo CAV. Impacto da política de Atenção Básica à Saúde na taxa de mortalidade infantil nos municípios brasileiros. Rev Política Hoje [Internet]. 2013 [citado 2014 set. 12];22(1). Disponível em: http://www.revista.ufpe.br/politicahoje/index.php/politica/article/ view/254/141

5. Macinko J, Starfield B, Erinosho T. The impact of primary heath care on population health in low and middle income countries. J Ambul Care Manage [Internet]. 2009 [cited 2012 Aug 10];32(2)150-71. Available from: http://www.ncbi.nlm.nih.gov/pubmed/19305227

6. Macinko J, Guanais F, Souza M. Evaluation of the impact of Family Health Program in infant mortality in Brazil. J Epidemiol Community Health [Internet]. 2006 [cited 2012 May 13];60(1):13-9. Available from: http://www.ncbi.nlm.nih.gov/pmc/articles/PMC2465542/

7. Chomatas ERV, Vigo A, Marty I, Hauser L, Harzhein E. Avaliação da presença e extensão dos atributos da atenção primária em Curitiba. Rev Bras Med Fam Comunidade [Internet]. 2013 [citado 2014 mar. 26];8(29):294-303. Disponível em: http://www.rbmfc.org.br/rbmfc/ article/viewFile/828/587

8. Harzhein E, Stein AT, Álvares-Dardet C. A efetividade dos atributos da Atenção Primária sobre a saúde infantil. Bol Saúde (Porto Alegre). 2004;18(1):24-40.

9. Starfield B, Shi L, Macinko J. Contribution of primary care to heath systems and health. Milbank Q. 2005;83(3):457-502.

10. Brasil. Ministério da Saúde; Secretaria de Atenção à Saúde, Departamento de Atenção Básica. Manual do Instrumento de Avaliação da Atenção Primária à Saúde: Primary Care Assessment Tool - PCATool - Brasil [Internet]. Brasília; 2010 [citado 2012fev. 17]. Disponível em: http://bvsms.saude.gov.br/bvs/publicacoes/manual_avaliacao_pcatool_brasil.pdf

11. Rocha PM, Uchoa AC, Rocha NSPD, Souza ECF, Rocha ML, Pinheiro TXA. Avaliação do Programa Saúde da Família em municípios do Nordeste brasileiro: velhos e novos desafios. Cad Saúde Pública [Internet]. 2008 [citado 2012 maio 20]. Disponível em: http://www. scielo.br/pdf/csp/v24s1/12.pdf

12. Harzheim E, Ducan BB, Stein AT, Cunha CRH, Gonçalves MR, Trindade TG, et al. Quality and effectiveness of different approaches to primary care delivery in Brazil. BMC Health Serv Res [Internet]. 2006 [cited 2014 May 6]. Available from: http://www.ncbi.nlm.nih.gov/ pmc/articles/PMC1790713/

13. Chomatas E, Vigo A, Marty I, Hauser L, Harzheim E. Avaliação da presença e extensão dos atributos da atenção primária em Curitiba. Rev Bras Med Fam Comunidade [Internet]. 2013 [citado 2014 maio 6];89(8). Disponível em: http://www.rbmfc.org.br/rbmfc/article/ viewFile/828/587

14. Colombo. Secretaria Municipal de Saúde; Conselho Municipal de Saúde. Plano Municipal de Saúde: $2010-2013$ [Internet]. Colombo (PR); 2010 [citado 2012 nov. 1]. Disponível em: http://www.colombo.pr.gov.br/downloads/saude/062012/PLANO-MUNICIPAL-DESAUDE-2010-13.PDF

15. Instituto Paranaense de Desenvolvimento Econômico e Social. Caderno Estatístico Município de Colombo [Internet]. Colombo (PR); 2010 [citado 2012 mar. 12]. Disponível em: http://www.ipardes.gov.br/cadernos/Montapdf.php?Municipio=83400\&btOk=ok

16. Victora CG, Barreto ML, Leal MC. Condições de saúde e inovações nas políticas de saúde no Brasil: um caminho a percorrer. Lancet Saúde no Brasil [Internet]. 2011 [citado 2012 maio 13];(6). Disponível em: http://download.thelancet.com/flatcontentassets/pdfs/brazil/ brazilpor6.pdf

17. Furtado MCC, Braz JC, Pina JC, Mello DF, Lima RAG. Assessing the care of children under one year old in Primary Health Care. Rev Latino Am Enfermagem. 2013;21(2):554-61.

18. Silva LA, Cassoti CA, Chaves SCL. A produção científica brasileira sobre a Estratégia Saúde da Família e a mudança no modelo da atenção. Ciênc Saúde Coletiva [Internet]. 2013 [citado 2013 out. 21];18(1):221-32. Disponível em: http://www.scielo.br/pdf/csc/v18n1/23.pdf

19. Saparolli EC, Adami NP. Evaluation of nursing consultation structure for children in Primary Health Care. Rev Esc Enferm USP. 2010;44(1):91-7.

20. Paim JS, Travassos C, Almeida C, Bahia L, Macinko J. O sistema de saúde brasileiro: história, avanços e desafios. Lancet Saúde no Brasil [Internet]. 2011 [citado 2013 out. 21];(1). Disponível em: http://download.thelancet.com/flatcontentassets/pdfs/brazil/brazilpor1.pdf

21. Santos SSBS, Silva LS, Carneiro EKN, Saback MAMC, Carvalho ESS. Processo de trabalho da equipe de Enfermagem em Unidades Saúde da Família em município baiano. Rev Baiana Enferm. 2013;27(2):101-7.

22. Machado CV, Baptista TWF, Lima LD, organizadores. Políticas de saúde no Brasil: continuidades e mudanças. Rio de Janeiro: FIOCRUZ; 2012.

23. Oliveira RL, Santos MEA. Educação em saúde na Estratégia Saúde da Família: conhecimentos e práticas do enfermeiro. Rev Enferm Integrada. 2011;4(2):833-44.

24. Mesquita Filho M, Luz BSR, Araújo CS. A Atenção Primária à Saúde e seus atributos: a situação das crianças menores de dois anos segundo suas cuidadoras. Ciênc Saúde Coletiva [Internet]. 2014 [citado 2014 ago. 21];19(7):2033-46. Disponível em: http://www.scielo.br/pdf/ csc/v19n7/1413-8123-csc-19-07-02033.pdf

25. D'Avila LS, Assis LN, Melo MB, Brant LC. Adesão ao Programa de Educação Permanente para médicos de família de um Estado da Região Sudeste do Brasil. Ciên Saúde Coletiva [Internet]. 2014 [citado 2014 maio 6];19(2):401-16. Disponível em: http://www.scielo.br/pdf/csc/ v19n2/1413-8123-csc-19-02-00401.pdf

26. Reis RS, Coimbra LC, Silva AAM, Santos AM, Alves MTSSB, Lamy ZC, et al. Acesso e utilização dos serviços na Estratégia Saúde da Família na perspectiva dos gestores, profissionais e usuários. Ciênc Saúde Coletiva [Internet]. 2013 [citado 2014 maio 6];18(11):3321-31. Disponível em: http://www.scielo.br/pdf/csc/v18n11/22.pdf 